JETE : VOL 2 NO 2 2021* E-ISSN : 2745-9888* P-ISSN : 2745-9896

Journal of Education and Teaching

http://ejournal.uin-suska.ac.id/index.php/JETE

THE EFFECT OF USING INFOGRAPHICS AND STUDENTS' READING INTEREST ON THEIR READING COMPREHENSION AT SMAN 16 PEKANBARU

\author{
Dian Eka Hertavira ${ }^{1}$ \\ Email: hertavira2805@gmail.com
}

Received: 30 Oktober 2019; Accepted 12 Agustus 2021; Published 1 September 2021

Ed 2021; 2 (2): 122-127

\begin{abstract}
ABSTRAK
Penelitian ini dilakukan dengan menerapkan penelitian eksperimen dan disain yang digunakan adalah disain faktorial $2 \times 2$. Tujuan penelitian ini adalah (1) untuk mengetahui apakah ada perbedaan pengaruh pemahaman membaca siswa antara kelas eksperimen dan kelas kontrol. (2) Untuk mengetahui perbedaan pemahaman membaca siswa antara siswa yang memiliki minat baca tinggi di kelas eksperimen dan kelas kontrol. (3) Untuk mengetahui perbedaan pemahaman membaca siswa antara siswa yang minat bacanya rendah pada kelas eksperimen dan kelas kontrol. (4) Untuk mengetahui apakah ada interaksi antara strategi mengajar dan minat baca terhadap pemahaman membaca siswa. Sampel penelitian adalah dua kelas siswa kelas XI IPS 1 dan IPS 2 SMAN 16 Pekanbaru. Penulis mengambil sampel dengan teknik cluster random sampling. Jumlah sampel adalah 60 siswa. Bentuk tesnya adalah tes pemahaman bacaan dan angket. Terakhir, hasil penelitian menunjukkan bahwa: pertama, terdapat skor signifikan (sig.) $0,02<0,05$ dalam pemahaman membaca siswa. Artinya ada perbedaan yang signifikan pada pemahaman membaca siswa antara kelas eksperimen dan kelas kontrol. Kedua, tidak terdapat perbedaan yang signifikan pada pemahaman membaca siswa antara siswa yang memiliki minat baca tinggi di kelas eksperimen dan kelas kontrol. Nilai sig adalah 0,841>0,05. Ketiga, terdapat perbedaan yang signifikan pada pemahaman membaca siswa antara siswa yang memiliki minat baca rendah di kelas eksperimen dan kelas kontrol. Nilai sig adalah 0,03>0,05. Terakhir, nilai sig adalah $0,045<0,05$. Artinya ada interaksi antara strategi mengajar dan minat baca terhadap pemahaman membaca siswa di SMAN 16 Pekanbaru.
\end{abstract}

Kata Kunci: Infografis, Minat Baca, Pemahaman Membaca

\title{
THE EFFECT OF USING INFOGRAPHICS AND STUDENTS' READING INTEREST ON THEIR READING COMPREHENSION AT SMAN 16 PEKANBARU
}




\begin{abstract}
This research was done by applying experimental research and the design used was factorial design $2 x 2$. The aims of this research were (1) to find out whether there is any different effect of students' reading comprehension between an experimental and control class. (2) To find out the different on students' reading comprehension between students who have high reading interest in an experimental class and a control class. (3) To find out the different on students' reading comprehension between students who have low reading interest in an experimental class and a control class. (4) To find out whether there is any interaction between teaching strategies and reading interest on students' reading comprehension. The samples were two classes of eleventh grade students of Social 1 and Social 2 of SMAN 16 Pekanbaru. The writer took the sample as cluster random sampling technique. The total sample was 60 students. The forms of the test were reading comprehension test and questionnaire. Finally, the results of the research show that: first, there was the significant score (sig.) $0.02<0.05$ in students' reading comprehension. It means that there is significant difference on students' reading comprehension between an experimental class and control class. Second, there was no significant difference on students' reading comprehension between students who have high reading interest in an experimental and control class. The sig value was $0.841>0.05$. Third, there was significant difference on students' reading comprehension between students who have low reading interest in an experimental and control class. The sig value was $0.03>0.05$. Last, the sig value was $0.045<$ 0.05. It means that there was an interaction between teaching strategy and reading interest on students' reading comprehension at SMAN 16 Pekanbaru.
\end{abstract}

Key words: Infographics, Reading Interest, Reading Comprehension

\title{
INTRODUCTION
}

Reading is the key to the learning process. When a person has good reading skills, He or he will be able to absorb various kinds of knowledge. This is important to increase the opportunity of the person to improve their lives. However, according to the results of the 2015 Program for International Student Assessment (PISA) on students' ability to read, Indonesia ranked 66 out of 72 countries surveyed. In the PISA results, Indonesian students achieved a score of 397 in reading ability. Compared to neighboring countries, Indonesia lags behind Malaysia in the 43rd rank with a score of 431 and Singapore ranked first with a score of 535.

Based on the researcher observation on April, 22, 2019 in SMAN 16 Pekanbaru, the researcher found that some of the students are not interest in reading. Many students still had low reading interest and low motivation in reading. The headmaster, teachers and staff already facilitated the students for reading interest. They already opened library and put several books. The teacher also made a one-page reading program one day. But in fact, the students ever visited library for reading book in time off. They preferred to sit and talk with friends. The cause factors were: First, they lacked of vocabulary. Second, they lacked of background knowledge. Third, text is unattractive reading. As a consequence, the students got lower score in exercise and exam because they didn't understand the questions and the texts. The students only guessed the answer without know the meaning of the word. The students did not master vocabulary well. As a consequence, they got difficult in interpreting the meaning. They just guessed the words because 
they did not use their dictionary in finding the meaning of unknown words. They were not able to find the main idea of the text and its supporting information. Last, the way they read text was monotonous. They did not have an innovative way to read a text comprehensively.

The English teachers had used many strategies in teaching learning process based on the materials and situation. The teacher also used media in teaching and learning process such as books, internet, PowerPoint, pictures, audio, and etc. But, it was not enough yet to help and motivate the students. So, the teacher should know the characteristics of the students. Regarding to the problems above, it is necessary for the teacher to use appropriate strategy in teaching reading comprehension. The writer proposes to use infographics in teaching reading comprehension. . Infographics is a visual representation of graphically data to convey complete information to the reader so that it can be understood more easily, quickly, concisely, and clearly.

\section{METHODOLOGY}

This research design used factorial design treatment. According to Fraenkel (2012:273) explains that factorial design is a modification of the pre-test and post-test controlled group. The design was factorial design treatment with level $2 \times 2$. A two by two factorial design refers to the structure of an experiment that studies the effect of a pair of two-level independent variables.

This research had three variables: two independent variables. First independent variable was using infographics (X1) and second independent variable was reading interest (X2), and dependent variable (variable $\mathrm{Y}$ ) was students' reading comprehension. In conducting the research, the reseacher used two classes. The first class was used for experimental group and second class was used for control group. Technique of Collecting Data, In order to get the data needed to support this research, the researcher will use:

\section{Observation}

Observation was the process of individual to get the information about others by viewing their action in the class. In this study, the researcher used the observation lists that must be fulfilled by the observer while in treatment process.

2. Questionnaire

In order to determine whether the students' reading interest was affected by through using infographics, it was used the questionnaire. Questionnaire aimed to identify the level of students' reading interest. It was designed based on Likert scale model

3. Test

According to Mary McDonald (2002:83), the multiple choice format can be used to asses a wide range of learning outcomes across all cognitive levels. Multiple choice items are adaptable to all types of subject matter; their scoring is accurate and efficient, and they provide students with practice for the type of items that they are likely to encounter on licensure and certification exams. The researcher used pre-test and post-test for experimental and control classes.

Technique of Analyzing Data, In this descriptive analysis is meant to get a general overview of the study result. The data obtained will be presented in the amount of descriptive statistics such as mean, median, mode, and standard deviation. Data analysis was conducted using a method of quantitative or statistical methods. Data analysis techniques used in this study 
is ANOVA. Before the ANOVA carried out, first tested with the data requirements of normality and homogeneity.

\section{RESEARCH FINDING}

Table 1

ANOVA 2X2

\begin{tabular}{|l|c|c|c|c|c|}
\hline \multicolumn{7}{|c|}{ Tests of Between-Subjects Effects } \\
\hline Dependent Variable:Comprehension & \multicolumn{1}{l|}{} \\
\hline Source & $\begin{array}{c}\text { Type III Sum of } \\
\text { Squares }\end{array}$ & Df & Mean Square & F & Sig. \\
\hline Corrected Model & $1070.933^{\text {a }}$ & 3 & 356.978 & 7.164 & .000 \\
\hline Intercept & 410026.667 & 1 & 410026.667 & $8.229 \mathrm{E} 3$ & .000 \\
\hline Strategy & 516.267 & 1 & 516.267 & 10.361 & .002 \\
\hline Interest & 345.600 & 1 & 345.600 & 6.936 & .011 \\
\hline Strategy * Interest & 209.067 & 1 & 209.067 & 4.196 & .045 \\
\hline
\end{tabular}

Table 1 shows that $p$ value (Sig) of teaching strategies was 0.02 which was $<$ than 0.05 , and $F$ observed was $10.361>3.16$. It means that $\mathrm{H}_{\mathrm{o}}$ was rejected and $\mathrm{H}_{1}$ was accepted. From the analysis in Table IV.12, it could be concluded there was a significant difference on students' reading comprehension between those who were taught by using infographics and who were taught by using conventional strategy.

Table 1 displays $p$ value ( $\mathrm{Sig}$ ) of reading comprehension was 0.045 which was < than 0.05 . It means that $\mathrm{H}_{\mathrm{o}}$ was rejected and $\mathrm{H}_{1}$ was accepted. From the analysis in Table IV.12, it could be concluded there was an interaction between using infographics and reading interest on students' reading comprehension. It means students' reading comprehension was influenced by using infographics and reading interest.

Table 2

\section{Multiple Comparisons}

\begin{tabular}{|c|c|c|c|c|c|c|}
\hline \multicolumn{2}{|c|}{\begin{tabular}{|l|} 
Comprehension \\
Tukey HSD \\
\end{tabular}} & \multirow{3}{*}{$\begin{array}{c}\text { Mean } \\
\text { Difference (I-J) }\end{array}$} & \multirow[b]{3}{*}{ Std. Error } & \multirow[b]{3}{*}{ Sig. } & \multirow{2}{*}{\multicolumn{2}{|c|}{ 95\% Confidence Interval }} \\
\hline \multirow[b]{2}{*}{ (I) $\mathbf{R I}$} & \multirow[b]{2}{*}{ (J) RI } & & & & & \\
\hline & & & & & Lower Bound & Upper Bound \\
\hline \multirow[t]{3}{*}{ HIGH INFO } & LOW INFO & $8.533^{*}$ & 2.578 & .009 & 1.71 & 15.36 \\
\hline & HIGH CONV & -2.133 & 2.578 & .841 & -8.96 & 4.69 \\
\hline & LOW CONV & -1.067 & 2.578 & .976 & -7.89 & 5.76 \\
\hline \multirow[t]{3}{*}{ LOW INFO } & HIGH INFO & $-8.533^{*}$ & 2.578 & .009 & -15.36 & -1.71 \\
\hline & HIGH CONV & $-10.667^{*}$ & 2.578 & .001 & -17.49 & -3.84 \\
\hline & LOW CONV & $-9.600^{*}$ & 2.578 & .003 & -16.43 & -2.77 \\
\hline
\end{tabular}

Table 2 describes that $p$ value $(\mathrm{Sig})$ of reading comprehension was 0.841 which was > than 0.05 . It means that $\mathrm{H}_{\mathrm{o}}$ was accepted and $\mathrm{H}_{1}$ was rejected. It shows that $p$ value was more significant than 0.05. From the analysis in Table IV.13, it could be concluded there was no significant difference on students' reading comprehension between students who have high 
reading interest that were taught by using infographics and those were taught by using conventional strategy.

The analysis of Table 2 shows that $p$ value (Sig) of reading comprehension was 0.03 which was $<$ than 0.05 . It means that $\mathrm{H}_{\mathrm{o}}$ was rejected and $\mathrm{H}_{1}$ was accepted. From the analysis in Table IV.13, it could be concluded there was a significant difference on students' reading comprehension between students who have low reading interest that were taught by using infographics and those were taught by using conventional strategy

\section{DISCUSSION}

Interest or willingness to read is a very important and powerful source of motivation for someone to analyze and remember and evaluate the reading that has been read because the person is reading a book indeed because he or she wants to read the book from the heart, which is an exciting learning experience. Infographics are graphic visual representations of information, data or knowledge_intended to present information quickly and clearly. They can improve cognition by utilizing graphics to enhance the human visual system's ability to see patterns and trends. In sum up, the difference between infographics and conventional strategy can be seen from learning activities done and reading process. In infographics, the teacher could put some information in creative way. Infographic requires a number of information in the form of writing and numbers and then converted into a simple form that is a combination of images and text that allows readers to quickly understand a message or picture itself. In addition, pictures, diagrams or maps will make it easier for students because the human brain tends to more easily store data in the form of images compared to writing. In addition, the use of language or sentences that are accompanied by interesting images can influence students to understand the material easily.

Infographics was not successful for the students who had high reading interest because the students would not pay attention to the information that they already know and understand. The other factors were the schedule of English subject. English subject started in the afternoon. It made the students felt sleepy and tired. Meanwhile, infographics was effective way to help the students who had low reading interest to comprehend the text because infographics display the information in short explanation. So, the students could understand the material clearly and effectively.

\section{CONCLUSION}

Infograhics can replace explanations that are too long, and replace tables complicated and full of number. Researchers said that delivering information visually has many advantages in comprehending the information. Information captured visually will be processed at the same time by brain. Meanwhile, information delivered by text, the information will be processed linearly. The advantages of using infographics can help the students in reading comprehension. The teacher could apply infographics in learning process. The teacher also should know the students' reading interest and motivate them to be able to place the subject taught. So, the students' skill of reading interest in learning process could be improved. The students could practice reading more. They can read what they want so that they would have an interest in reading. 


\section{REFERENCES}

Beeger, J. (2014). Infographics for Dummies. New Jersey: Jhon Wiley \& Sons, Inc.

Education Psychology Review Vol.13, 195.

Hidi, S. (2001). Interest, Reading, and Learning: Theoritical and Practical Consideration.

Lankow, J. (2012). Infographics, The Power of Visual Story Telling. Canada: Jhon Wiley \& Sons, Inc.

Safipoor, M. (2016). Infographic (information graphic); a tool for increasing the efficiency of teaching and learning processes . International Academic Journal of Innovative Research, $29-45$.

Sheng, H. J. (2000). A Cognitive Model for Teaching Reading Comprehension. English Teaching Forum, 12-17.

Smiciklas, M. (2012). The Power of Infographics. Indiana Polis: Que Publishing. Wallen, J. R. (2007). How to Design and Evaluate Research in Education. New York: McGraw-Hill Higher Education 